\title{
Spermatogenesis in house mouse in a Robertsonian polymorphism zone
}

\author{
$M^{\mathrm{a}}$ Assumpció Sans-Fuentes ${ }^{1,2}$, José García-Valero ${ }^{3}$, Jacint Ventura ${ }^{4}$ and $\mathrm{M}^{\mathrm{a}}$ José López-Fuster ${ }^{2}$ \\ ${ }^{1}$ Department of Ecology and Evolutionary Biology, The University of Arizona, 1041 East Lowell Street, Tucson, \\ Arizona 85721, USA, ${ }^{2}$ Departament de Biologia Animal, Facultat de Biologia, Universitat de Barcelona, Avenida \\ Diagonal 645, 08028 Barcelona, Spain, ${ }^{3}$ Departament de Biologia Cel.lular, Facultat de Biologia, Universitat de \\ Barcelona, Avenida Diagonal 645, 08028 Barcelona, Spain and ${ }^{4}$ Departament de Biologia Animal, de Biologia \\ Vegetal i d'Ecologia, Facultat de Biociènces, Universitat Autònoma de Barcelona, 08193 Bellaterra, Spain
}

Correspondence should be addressed to $\mathrm{M}^{\mathrm{a}} \mathrm{A}$ Sans-Fuentes at Department of Ecology and Evolutionary Biology, The University of Arizona; Email: sans@email.arizona.edu

\begin{abstract}
Robertsonian ( $\mathbf{R b})$ translocations can be important in speciation as a mechanism of postzygotic isolation between populations. Meiotic non-disjunction, gametogenic impairment, and association of impaired autosomal segments with sex chromosomes have been postulated as mechanisms responsible for reducing fertility in $\mathrm{Rb}$ mice. Quantitative histological studies needed to understand the role of Rb fusions in gametogenic impairment are scarce. Most research on $\mathbf{R b}$ mice has analyzed meiotic non-disjunction of laboratory and wild-derived strains, which have complex or simple structural heterozygosity with large numbers of fusions. Using histological multilevel sampling, we examined spermatogenesis in mice from the $\mathbf{R b}$ polymorphism area of Barcelona. We studied four chromosomal groups having: $\mathbf{a}$ ) one $\mathrm{Rb}$ heterozygote fusion and $2 n=39$, b) one Rb heterozygote fusion and $2 n=31$, c) three Rb heterozygote fusions without monobrachial homology and with diploid number ranging from $2 n=29$ to $2 n=37$, and d) only Rb homozygote fusions with diploid number ranging from $2 n=28$ to $2 n=30$. Standard mice from the area surrounding the Rb zone were used as control. We analyzed morphological variables of the testes, relative frequency of stages in the seminiferous epithelium cycle, the 'round spermatids:primary spermatocytes' ratio, and other derived parameters. Our results reveal that structural homozygote mice and simple heterozygote mice having as few as one to three $\mathbf{R b}$ fusions undergo greater germ cell death (GCD) than standard mice, suggesting that $\mathbf{R b}$ fusions are related to increased GCD (in both the heterozygous and homozygous state) and may be the main cause of decreased gene flow between mice populations from this area.
\end{abstract}

Reproduction (2010) 140 569-581

\section{Introduction}

Chromosome rearrangements can play an important role in speciation by acting as a mechanism of postzygotic isolation between chromosomally differentiated populations, either preventing the formation of hybrids or producing hybrids with reduced viability or with partial or complete sterility (King 1993, Spirito 2000, Rieseberg 2001). The Robertsonian (Rb) translocation, i.e. a centric fusion between two telocentric chromosomes to form a metacentric one, is a chromosomal rearrangement widely found between and within species. It has a high spontaneous mutation rate (estimated accurately only in humans: $1.0 \times 10^{-4}$ per gamete per generation; Jacobs 1981) and is present in high frequency in some mammal populations (e.g. Baker \& Bickham 1986, Piálek et al. 2005, Basset et al. 2008, Mao et al. 2008, Robinson et al. 2008). This, together with its effects in the reduction of both fertility and recombination (especially in animals with $\mathrm{Rb}$ translocations in heterozygosis), suggests that $\mathrm{Rb}$ fusions may play an important role in speciation (e.g. Rieseberg 2001, Capanna \& Castiglia 2004). Moreover, several studies have supported the idea that $\mathrm{Rb}$ fusions cause reproductive isolation in a number of mammal species (Theiler \& Blanco 1996, De Oliveira et al. 2000, Rogatcheva et al. 2000, Fernández-Donoso et al. 2001, Jadwiszczak \& Banaszek 2006, Lanzone et al. 2007, Franchini et al. 2008).

The western house mouse (Mus musculus domesticus, also referred to as $M$. domesticus) has extremely high karyotypic diversity. Its standard karyotype is 40 telocentric chromosomes, but the presence of $\mathrm{Rb}$ fusions can lead to a diploid number ranging between 22 and 39 chromosomes (Piálek et al. 2005, Sans-Fuentes et al. 2007, Solano et al. 2007, Burt et al. 2009). Heterozygotes for Rb translocations can occur either at hybrid zones between karyotypic races (for definition of race, see Hausser et al. (1994)) or in areas of Rb polymorphism 
(Gündüz et al. 2001, Sans-Fuentes et al. 2007), and they can act as isolating barriers between populations. Meiotic non-disjunction (e.g. Gropp et al. 1982), meiotic failure (Miklos 1974, Burgoyne \& Baker 1984, Manterola et al. 2009), and association of impaired autosomal segments with sex chromosomes (Johannisson \& Winking 1994) have been postulated as mechanisms responsible for the reduction in fertility in carriers of heterozygous $\mathrm{Rb}$ fusions. They may, therefore, act as postmating isolating mechanisms. To date, two major conclusions can be drawn from the research on fertility of $\mathrm{Rb}$ mice: 1) reduction in fertility is more severe in complex heterozygotes characterized by one or more metacentrics with monobrachial arm homology than in simple heterozygotes characterized by one or multiple heterozygotes each one complemented by its homologous telocentrics (Redi \& Capanna 1988, Hauffe \& Searle 1998); 2) simple heterozygotes have a significant reduction in fertility associated with the presence of seven to nine heterozygous $\mathrm{Rb}$ fusions (Hauffe \& Searle 1998, Castiglia \& Capanna 2000, Wallace et al. 2002, Merico et al. 2003, Manterola et al. 2009), while when the number $\mathrm{Rb}$ fusions is low (from 1 to 3 ), less important alterations in reproduction have been detected (Britton-Davidian et al. 1990, Wallace et al. 1992, Hauffe \& Searle 1998, Wallace 2003). These conclusions are based mainly on a number of analyses of meiotic non-disjunction of multivalents in structural heterozygotes (e.g. Baker \& Bickham 1986, King 1993, Castiglia \& Capanna 2000) and on a few histological studies conducted mainly in both laboratory and wildderived strains (e.g. Redi \& Capanna 1988 and references therein, Garagna et al. 2001, Wallace et al. 2002, Merico et al. 2003, 2008). There is little literature on histological studies of wild populations of mice, and these have focused mainly on the variation of the 'round spermatids:primary spermatocytes' ratio in mice with a high number of heterozygous $\mathrm{Rb}$ fusions (Wallace et al. 1992, Hauffe \& Searle 1998, Wallace et al. 2002). Studies on this subject are important for several reasons. On the one hand, quantitative histological data are necessary to develop a proper understanding of the relationship between $\mathrm{Rb}$ fusions and gametogenic impairment. On the other hand, studies in wild populations may reveal how genetic isolation between $\mathrm{Rb}$ populations is proceeding. Hybrid zones between $\mathrm{Rb}$ races are especially relevant, since these zones may represent a barrier to gene flow (Panithanarak et al. 2004, Franchini et al. 2008), and their structure and extension are partially determined by the degree of selection against hybrids. Moreover, as these populations have been through several generations of natural selection, a reduction in meiotic aberrations in Rb heterozygotes is expected, when compared with hybrids from laboratory crosses between wild-derived strains, between laboratory strains or between wild-derived and laboratory strains.
Here, we compare spermatogenesis in wild mice from the $\mathrm{Rb}$ polymorphism area of Barcelona, where only simple heterozygotes have been found (for a detailed description of this zone, see Gündüz et al. (2001) and Sans-Fuentes et al. (2007)). Although this area is not a typical hybrid zone between $\mathrm{Rb}$ races, a reduction in gene flow between populations is occurring, since both morphological (Muñoz-Muñoz et al. 2003, 2006, Sans-Fuentes et al. 2009) and ethological (Sans-Fuentes et al. 2005) differentiation have been detected between animals differing in karyotypes. Specifically, we studied spermatogenesis by a histological multilevel sampling of standard mice (40ST), considered as a control group since a normal progression of spermatogenesis is expected in these animals, and four Rb groups having: a) one $\mathrm{Rb}$ heterozygote fusion and $2 n=39$ (heterozygotes I-39, $\mathrm{HTI}-39)$, b) one $\mathrm{Rb}$ heterozygote fusion and $2 n=31$ (heterozygotes I-31, HTI-31), c) three Rb heterozygote fusions without monobrachial homology and with a diploid number ranging from $2 n=29$ to $2 n=37$ (heterozygotes III, HTIII), and d) only Rb homozygote fusions with a diploid number ranging from $2 n=28$ to $2 n=30(\mathrm{HH})$. This study represents the first time that mice (within a polymorphic Rb area) having only one fusion, which is in heterozygosis, are compared with $\mathrm{Rb}$ heterozygotes mice with many $\mathrm{Rb}$ fusions in homozygosis, and to Rb homozygous mice. Moreover, most previous studies on wild mice from $\mathrm{Rb}$ zones have focused on multiple and complex heterozygotes, while spermatogenesis studies conducted on simple heterozygotes and on structural homozygotes are scarce (Redi \& Capanna 1988, Wallace et al. 1992, Hauffe \& Searle 1998). Therefore, the results obtained here contribute to completing the information on $\mathrm{Rb}$ metacentric effects in germ cell death (GCD), especially when the number of fusions in heterozygosis is low.

\section{Results \\ Standard mice have bigger testes than $\mathbf{R} b$ mice}

As a first approximation to study a possible reduction in spermatogenic cells in $\mathrm{Rb}$ mice, we analyzed the volume of the testis and the length of the seminal vesicle (space $\Omega_{0}$; Fig. $\left.1 \mathrm{~A}\right)$ in a sample of 61 mice $\left(n_{40 \mathrm{ST}}=17 ; n_{\mathrm{HH}}=11\right.$; $n_{\mathrm{HTI}-31}=10 ; n_{\mathrm{HTI}-39}=10 ;$ and $\left.n_{\mathrm{HTIII}}=13\right)$. The relative testis volume (testis volume in $\mathrm{mm}^{3}$ /body mass in $\mathrm{g}$ ) was different between the chromosomal groups $(F=4.76$, $P<0.01)$. Although 40ST mice had the higher mean $\left(\bar{X}_{40 \mathrm{ST}}=0.00488 \pm 0.00021 ; \bar{X}_{\mathrm{HH}}=0.00435 \pm 0.00016\right.$; $\bar{X}_{\mathrm{HT} 1-31}=0.00352 \pm 0.00027 ; \bar{X}_{\mathrm{HT} 1-39}=0.00437 \pm 0.00029 ;$ and $\bar{X}_{\text {HTIII }}=0.00389 \pm 0.00027$ ), a post-hoc Tukey's test revealed that only the groups HTI-31 and HTIII had significantly smaller means than the group 40ST $(P<0.01$ and $P<0.05$ respectively). The mean values of relative vesicle size did not differ significantly between the chromosomal groups. 
$\Omega_{0}$

A

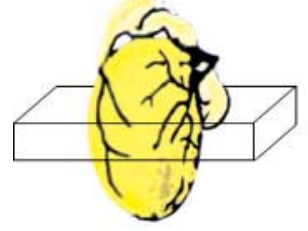

$\Omega_{1}$

B

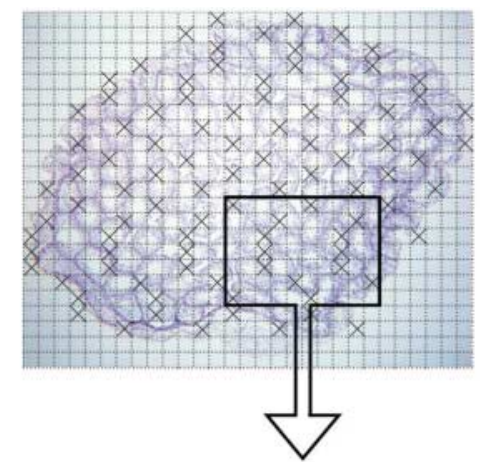

C

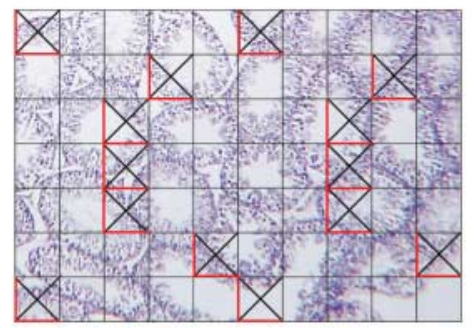

$\Omega_{2}$

D

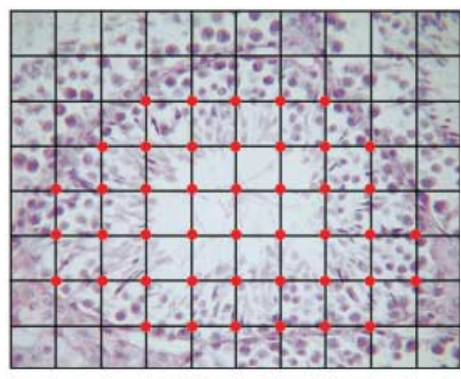

E

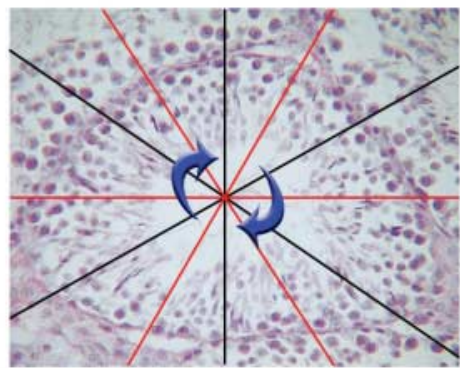

Figure 1 Multiphasic hierarchical sampling. (A) Testis $\left(\Omega_{0}\right.$ space) with the central section highlighted. (B) Cross-section of the testis at $40 \times\left(\Omega_{1}\right.$ space) projected, using a camera lucida (Olympus $\mathrm{BH} 2-\mathrm{DA}$ ), on a $0.5 \times 0.5-\mathrm{cm}^{2}$ grid; the crosses show the selected squares (one out of every five inside the grid limited by the cross-section). (C) Cross-section of the testis observed at $100 \times$. One out of every five squares was selected, starting in the top left of the projection and following systematically from left to right and top to bottom. The exclusion limits are highlighted in red. (D) Cross-section of a seminiferous tubule at $400 \times$ projected in a coherent grid of equidistant points; the points counted for the estimation of the areas are shown in red. (E) Cross-section of a seminiferous tubule at $400 \times$ projected, with a camera lucida, onto a radial grid of 12 sectors with a nominal angle of $30^{\circ}$; every other sector was selected for counting; the exclusion line is highlighted in red, i.e. the cells that touch this line are not taken into account.

\section{The seminiferous epithelium cycle proceeds according to the expected pattern in $\mathrm{Rb}$ mice}

To determine whether the succession of maturation stages is altered in Rb mice, we calculated, in space $\boldsymbol{\Omega}_{1}$ (Fig. 1B and C), the relative frequency of stages in the seminiferous epithelium cycle. To this end, as for the rest of the histological analysis, we used a subsample of 25 mice (five from each chromosomal group; Table 1). We did not detect significant differences between the chromosomal groups in the relative length of the epithelium maturation stages. The length values described in our study were consistent with those described in other studies on laboratory mice strains (Table 2; Clermont \& Trott 1969). This suggests that the succession of maturation stages proceeds according to the expected pattern.

\section{Reduction in spermatogenic activity in Rb mice}

Spermatogenic activity and spermatogenic state of the tubules were studied by measuring the diameter of the tubule and the volume density of the epithelium respectively (space $\Omega_{2}$; Fig. 1D). The minor diameter of the tubular cross-section showed significant differences between the chromosomal groups $(F=4.54, P<0.01)$ and animals $(F=10.28, P<0.001)$. The group 40ST had significant higher mean diameter than the groups HTI-39 and HTIII $(P<0.05)$; no significant differences were found between the groups $\mathrm{HH}, \mathrm{HTI}-31, \mathrm{HTI}-39$, and HTIII (Fig. 2A). All groups except HH showed differences between animals. Despite high individual variance, 40ST mice had a higher frequency of tubules with diameter $>150 \mu \mathrm{m}$, whereas in Rb mice, most tubules had diameters smaller than $150 \mu \mathrm{m}$. The volume density of the epithelium showed significant differences between the chromosomal groups $(F=20.12, P<0.001)$ and between animals $(F=7.55 ; P<0.001)$. The groups $\mathrm{HH}$ and HTIII had less epithelium than the groups 40ST $(P<0.05, \quad P<0.001$ respectively), HTI-31 $(P<0.01$, $P<0.001$ respectively), and $\mathrm{HTI}-39(P<0.001$ in both the cases; Figs $2 \mathrm{~B}$ and $3 \mathrm{~A}$ and $\mathrm{B}$ ). No significant differences were observed between the groups 40ST, HTI-31, and HTI-39. Differences between individual means of the volume density of the epithelium were significant in all the groups.

\section{Higher GCD during meiosis in $\mathrm{Rb}$ mice correlated positively with the number of $R b$ translocations}

Also in space $\Omega_{2}$, the number of round spermatids $(\beta)$ and pachytene spermatocytes $(\alpha)$ were counted to calculate several informative variables of cell population in the 


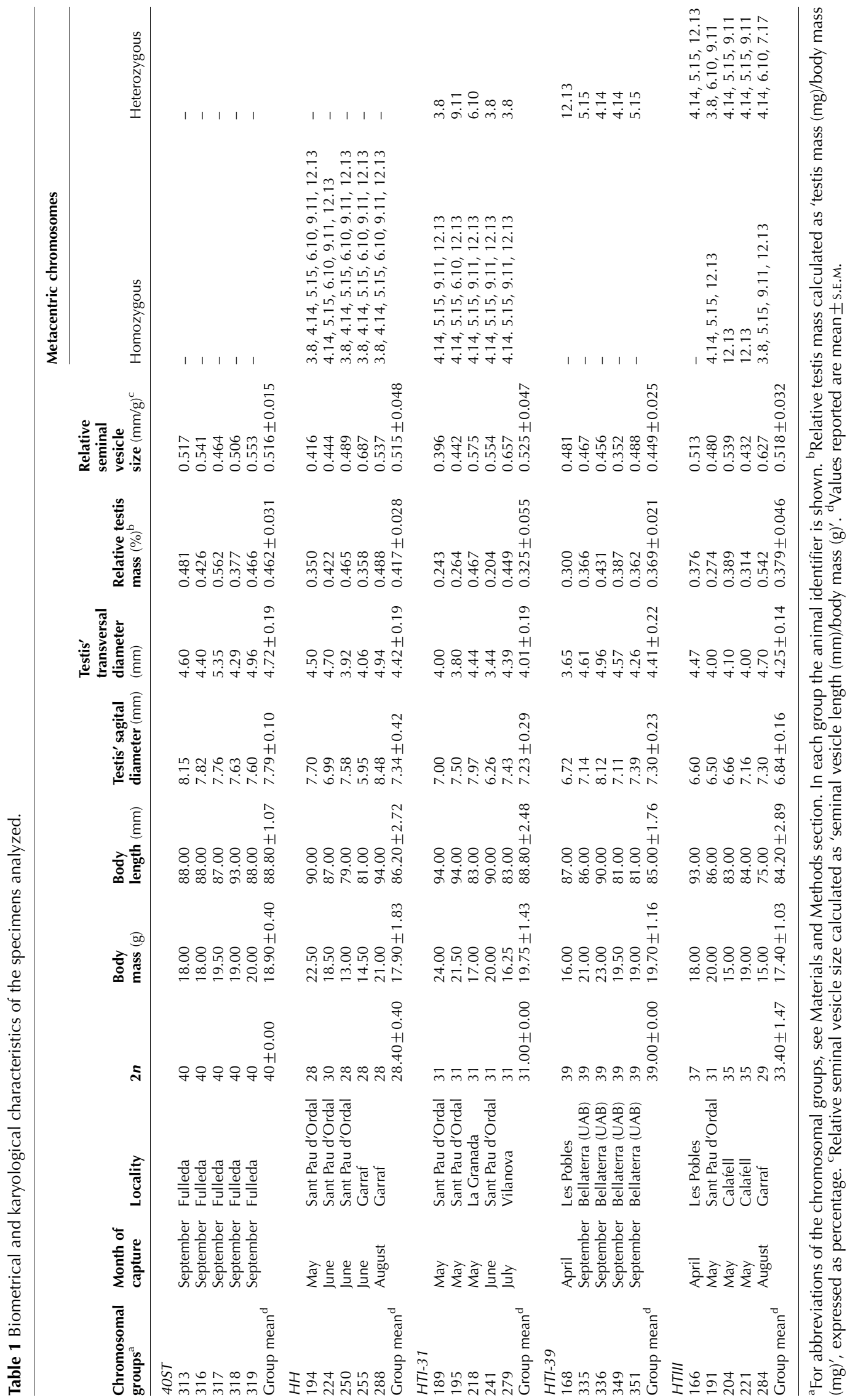


Table 2 Relative mean length of the stages of the seminiferous epithelium cycle in each chromosomal group analyzed. Values reported are mean \pm S.E.M.

\begin{tabular}{|c|c|c|c|c|c|c|c|}
\hline \multirow[b]{2}{*}{ Stage } & \multicolumn{7}{|c|}{ Relative mean length (\%) } \\
\hline & 40ST & $\mathrm{HH}$ & HTI-31 & HTI-39 & HTIII & $\mathrm{C} 3 \mathrm{H}$ & $\begin{array}{c}\text { Swiss } \\
\text { albino mice }\end{array}$ \\
\hline I & $12.08 \pm 3.93$ & $12.36 \pm 7.72$ & $17.8 \pm 1.99$ & $15.98 \pm 7.12$ & $8.58 \pm 3.80$ & 11.12 & 11.73 \\
\hline |I-III & $10.78 \pm 2.74$ & $6.12 \pm 1.78$ & $8.72 \pm 2.21$ & $10 \pm 4.19$ & $11.88 \pm 5.13$ & 8.85 & 7.91 \\
\hline IV & $6.14 \pm 2.33$ & $6.48 \pm 2.30$ & $5.9 \pm 2.79$ & $7.24 \pm 2.83$ & $6.5 \pm 2.87$ & 9.11 & 10.26 \\
\hline $\mathrm{V}$ & $4.68 \pm 2.89$ & $3.76 \pm 1.45$ & $4.06 \pm 1.32$ & $4.7 \pm 1.08$ & $7.94 \pm 3.24$ & 8.77 & 8.58 \\
\hline VI & $7.78 \pm 2.93$ & $9.12 \pm 1.29$ & $5.26 \pm 3.62$ & $8.64 \pm 3.31$ & $6.76 \pm 2.86$ & 8.85 & 6.98 \\
\hline VII & $18.7+1.39$ & $16.32+3.20$ & $18.82+3.80$ & $19.42+3.28$ & $19.14+5.45$ & 14.38 & 15.16 \\
\hline VIII & $3.56 \pm 2.63$ & $6.58 \pm 3.62$ & $4.66 \pm 2.48$ & $4.9 \pm 3.33$ & $4.58 \pm 1.90$ & 6.85 & 8.39 \\
\hline IX & $12.1 \pm 4.96$ & $13 \pm 2.66$ & $13.48 \pm 2.03$ & $10.06 \pm 2.47$ & $11.44 \pm 2.19$ & 8.26 & 9.59 \\
\hline$x$ & $4.66+2.53$ & $5.02+2.61$ & $5.04+2.46$ & $3.46+1.31$ & $5.52+2.30$ & 3.66 & 4.16 \\
\hline XI & $6.98 \pm 2.90$ & $6.78 \pm 4.52$ & $6.2 \pm 0.97$ & $5.82 \pm 2.91$ & $4.6 \pm 1.73$ & 9.87 & 8.45 \\
\hline XII & $12.66+3.36$ & $14.36+5.66$ & $10.06+4.48$ & $9.76+2.94$ & $13.12+4.82$ & 10.51 & 8.86 \\
\hline
\end{tabular}

The last two columns summarize the values obtained by Clermont \& Trott (1969) in C3H and Swiss albino mice.

testis. As a measurement of GCD during meiosis, we calculated the $\beta: \alpha$ ratio. Chromosomal groups and animals differed significantly for this ratio $(F=41.28$, $P<0.001$ and $F=4.74, P<0.001$ respectively; Table 3$)$. A posteriori post-hoc Tukey's test did not reveal significant differences between the groups $\mathrm{HH}, \mathrm{HTI}-31$, and HTI-39. These groups showed intermediate $\beta: \alpha$ values, with lower values than the group 40ST $(P<0.001)$ and higher values than the group HTIII $(P<0.001$; Table 3, Fig. 2C). The percentages of GCD were $19.51 \%$ for 40 ST and $39.61 \%$ for HTIII groups (Table 3). Further analysis using Student's $t$-test corrected by the method of Bonferroni (Rice 1989) revealed that some groups were significantly heterogeneous (Table 3 ). The distribution of cell death among tubules was estimated as the percentage of defective tubules per animal ( $\%$ DT). For the criterion $\%$ DT $<3$ (i.e. percentage of tubules with $\beta: \alpha$ ratio lower than $3: 1$ ), significant differences between the groups were detected $(F=8.71, P<0.001)$. The group 40ST had the lowest mean $(P<0.05$ when compared with the groups $\mathrm{HH}$ and HTI-39; $P<0.01$ when compared with the group HTI-31; $P<0.001$ when compared with the group HTIII). No differences were detected between the $\mathrm{Rb}$ groups (Table 3, Fig. 2D). Under the criterion \% DT $<2$, significant differences were also detected between the groups $(F=3.48, P<0.05)$; the group 40ST had a lower mean value than the group HTIII $(P<0.05)$. For criterion \% DT $<1$, only two animals belonging to the group HTIII - had $\beta: \alpha<1: 1$ (Table 3).
A

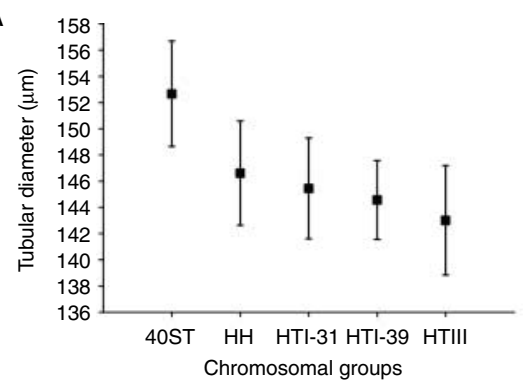

D

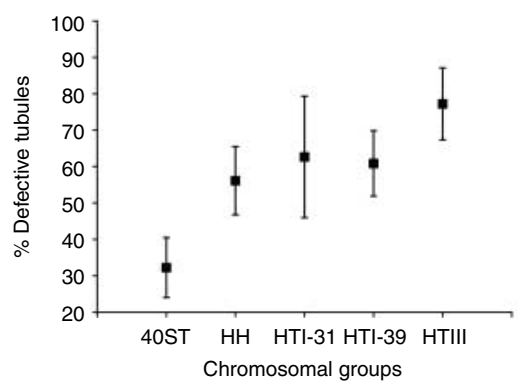

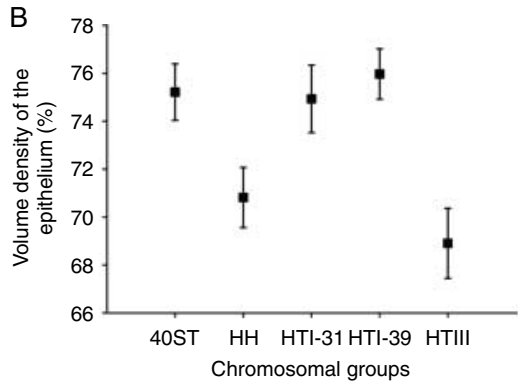

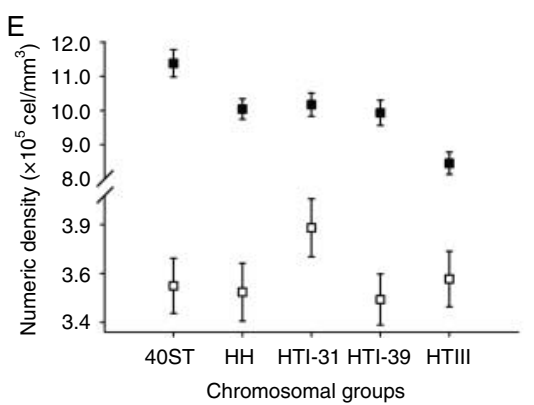

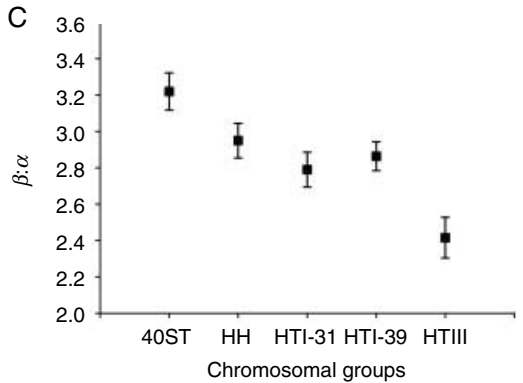

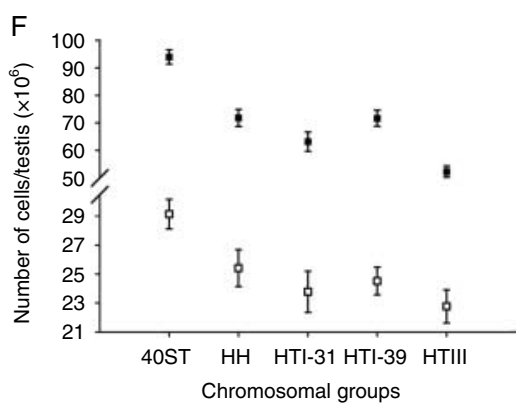

Figure 2 (A) Seminiferous tubule diameter. (B) Volume density of the epithelium. (C) Spermatids:spermatocytes ratio ( $\beta$ : $\alpha$ ). (D) Percentage of defective tubules under the criteria $\beta: \alpha<3: 1$. (E) Numeric density of spermatids (filled symbols) and spermatocytes (empty symbols). (F) Total number of spermatids (filled symbols) and spermatocytes (empty symbols) in the testis. Mean \pm 2 S.E.M. is represented. 


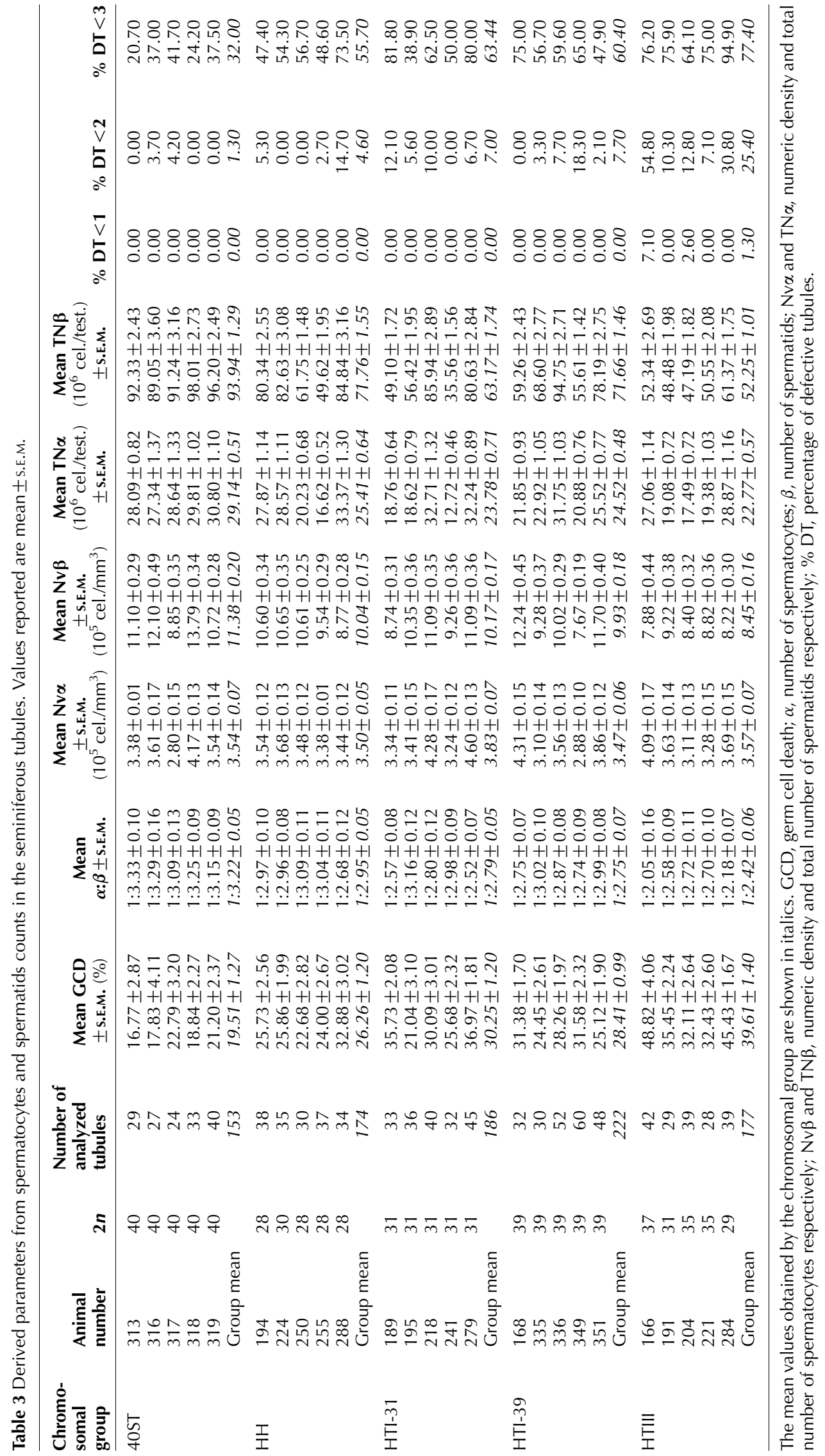



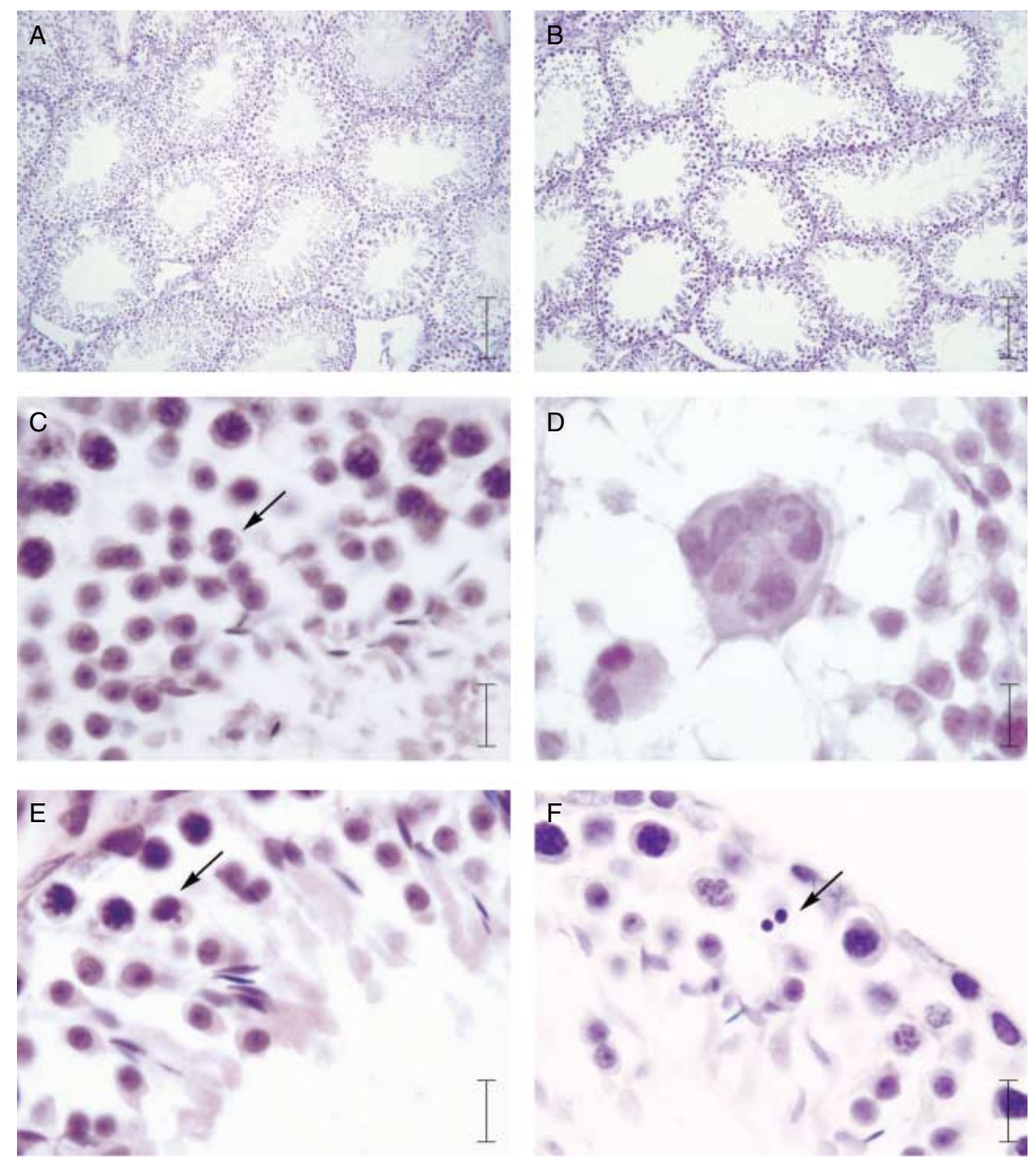

Figure 3 ( $\mathrm{A}$ and $\mathrm{B}$ ) Histological section of the seminiferous tubules $(100 \times)$ of specimens 313 (40ST) and 166 (HTIII) respectively.

(C) Binucleated spermatid $(1000 \times)$ observed in the cross-section of a seminiferous tubule at stage VI of the specimen $224(\mathrm{HH})$.

(D) Symplastic spermatids $(1000 \times)$ observed in the cross-section of a seminiferous tubule at stage $\mathrm{V}$ of specimen 284 (HTIII). (E) Apoptotic cell $(1000 \times)$ found in a seminiferous tubule in stages II-III of specimen 218 (HTI-31). (F) Apoptotic cell $(1000 \times)$ found in a seminiferous tubule in stage $\mathrm{VI}$ of specimen 166 (HTIII). The scale bar represents $100 \mu \mathrm{m}$ in $\mathrm{A}$ and $\mathrm{B}$ and $10 \mu \mathrm{m}$ in C-F. The histological cross-section was stained with periodic acid-Schiff (P.A.S.) and contrasted with hematoxylin.
Light microscopic observation on testis cross-sections revealed that apoptotic spermatids and abnormal multinucleated syncytia (symplast) were prevalent in HTIII mice. Binucleated spermatids were also frequently observed in $\mathrm{HH}, \mathrm{HTI}-31$, and $\mathrm{HTI}-39$ mice (Fig. 3C-F).

\section{Reduction in the number of primary spermatocytes per testis in Rb mice}

Because the number of round spermatids and primary spermatocytes provide additional information on meiotic and pre-meiotic GCD respectively, we calculated the numeric densities and the total number of cells for round spermatids $(N v \beta$ and $T N \beta)$ and primary spermatocytes $(\mathrm{N} v \alpha$ and $\mathrm{TN} \alpha)$.

$N v \beta$ and $N v \alpha$ were significantly different between the chromosomal groups $(N v \beta: F=36.91, P<0.001$; Nva: $F=3.59, P<0.05)$ and animals $(\operatorname{Nv} \beta: F=13.91$, $P<0.001$; Nva: $F=12.35, P<0.001)$. The post-hoc Tukey test for $N v \beta$ revealed the same pattern found for $\beta: \alpha$; the group 40ST had the highest average $(P<0.001)$, and the group HTIII had the lowest, while no significant differences were observed between the groups $\mathrm{HH}, \mathrm{HTI}-$ 31, and HTI-39 ( $P<0.001$; Table 3, Fig. 2E). This result confirms GCD during meiosis. All groups, except HTIII, showed significant differences for $N v \beta$ between animals (Table 3). Nevertheless, for $\mathrm{Nv} \alpha$ only significant differences between the groups $\mathrm{HTI}-31$ and 40ST were found, with HTI-31 showing the highest value $(P<0.01$; Fig. 2E). Significant differences between animals were also detected for $\mathrm{Nv} \alpha$, in all groups except in $\mathrm{HH}$ (Table 3).

The total number of cells was different between the groups (TN $\beta$ : $F=142.78, P<0.001 ; \mathrm{TN} \alpha: F=34.17$, $P<0.001)$ and between animals (TN $\beta: F=30.11$, $P<0.001 ; \mathrm{TN} \alpha: F=43.04, P<0.001)$. Further analyses using the post-hoc Tukey test for TN $\beta$ showed that the group 40ST had the highest value, and the group HTIII had the lowest. The groups HH, HTI-31, and HTI-39 had intermediate mean values, with HTI-31 showing lower values than $\mathrm{HH}$ and $\mathrm{HTI}-39$. All these differences were significant at $P<0.001$ (Table 3, Fig. 2F). For TN $\alpha$ values, the group 40ST had the highest mean value $(P<0.001)$, and the group HTIII had the lowest $(P<0.001$, when compared with the groups 40ST and $\mathrm{HH} ; P<0.05$, when compared with the group HTI-39). The groups HTI-31 and HTIII were not significantly different (Table 3, Fig. 2F). All groups, except 40ST, showed differences between specimens for TN $\beta$ and TN $\alpha$ (Table 3). 


\section{Discussion}

Our results on GCD and spermatogenic activity-related parameters indicate a reduction in spermatozoid production in mice from the $\mathrm{Rb}$ zone of Barcelona, especially in those with three heterozygous fusions. Since a positive correlation between the mass of the testis and the number of spermatogenic cells has been reported in the house mouse (Searle \& Beechey 1974, Meistrich 1982, Sinha Hikim et al. 1989), we analyzed the size of the reproductive organs in animals from different chromosomal groups. We found a tendency for standard animals to have higher values of relative testis size than $\mathrm{Rb}$ mice. This corroborates previous results obtained in other $\mathrm{Rb}$ zones where differences in testis mass between standard and $\mathrm{Rb}$ mice were detected (Wallace et al. 1992, Hauffe \& Searle 1998, Chatti et al. 2005).

Unlike other studies, we did not find spermatogenic arrest or delay in the maturation of the seminiferous epithelium. However, Redi et al. (1985) and Eaker et al. (2001) observed a delay in spermatogenesis at stage XII with an increase of apoptotic cells, suggesting the loss of spermatocytes during the first meiotic division. This inconsistency between the results could be due to differences between the number and type of metacentrics carried by the specimens. According to Hauffe \& Searle (1998), an increase in the number of heterozygous fusions and especially the presence of fusions with monobrachial homology can have drastic effects during spermatogenesis. It should be borne in mind that, whilst our study analyzed mice with a maximum number of three $\mathrm{Rb}$ fusions in heterozygosis, animals in the study by Eaker et al. (2001) were structural heterozygotes for four $\mathrm{Rb}$ translocations. Likewise, Redi et al. (1985) focused their research on animals carrying two or more fusions but with monobrachial homology. Moreover, the animals in their studies were hybrids from crosses between different laboratory strains or wild-derived strains; thus, genetic background incompatibility can be an additional factor in spermatogenic arrest.

Mice from the Rb polymorphism area of Barcelona had significantly smaller diameters of the seminiferous tubules than the standard mice. A positive relationship between the tubular diameter and the spermatogenic activity of testis has been reported (Sinha Hikim et al. 1989), with the tubular diameter being a better indicator than the testis mass for discriminating between different levels of spermatogenic alterations (Russell et al. 1990). Therefore, these results indicate lower spermatogenic activity in Rb mice (heterozygotes and homozygotes) than in 40ST ones. Previous studies also reported a reduction in the tubular diameter in simple $\mathrm{Rb}$ heterozygote mice carrying nine fusions and in backcrosses of these hybrids with the parental races (Said et al. 1993, Chatti et al. 2005).
Our results on the volume density of the epithelium indicate that $\mathrm{HH}$ mice, and especially HTIII mice, have a smaller fraction of the tubule occupied by cells. This suggests that the cell population in these two groups is substantially smaller than that in 40ST mice. To our knowledge, other authors studying fertility in $\mathrm{Rb}$ mice did not quantify the fraction of the seminiferous tubules filled by cells. However, qualitative histological observations reveal that subfertile and sterile $\mathrm{Rb}$ mice can show bigger areas of lumen than the standard mice (e.g. Fig. 5 in Capanna et al. (1976), Fig. 2 in Redi et al. (1985), Fig. 1d in Said et al. (1993), Fig. 3 in Garagna et al. (2001); Fig. 1c in Merico et al. (2003)).

The smaller testis sizes, lower spermatogenic activity, and smaller volume density in mice from the $\mathrm{Rb}$ polymorphism area of Barcelona can be partially explained by a decrease in the number of spermatids. Mice from the $\mathrm{Rb}$ area (especially those from HTIII) showed lower $\beta: \alpha, N v \beta$, and $\operatorname{TN} \beta$ values, and higher percentages of GCD than the standard mice, suggesting a reduction in the spermatid population when $\mathrm{Rb}$ translocations are present. The decrease in spermatid numbers was greater in mice with three Rb heterozygote fusions. This result was also supported by direct observations of the cross-sections under the light microscope, since symplastic and apoptotic spermatids were frequently observed in Rb mice (Fig. $3 \mathrm{C}-\mathrm{F}$ ). It is worth noting that GCD is not homogeneous among tubules. Whereas the \% DT with $\beta: \alpha<3: 1$ barely exceeded $40 \%$ in 40 ST specimens, it oscillated between 39 and $95 \%$ in the Rb groups. The highest \% DT under the criterion $\beta: \alpha<2: 1$ was observed in the HTIII group; and only in this group were animals meeting the criterion $\beta: \alpha<1: 1$ found.

GCD values obtained in mice from the Rb polymorphism area of Barcelona show that the main factor responsible for the positive association between $\mathrm{Rb}$ translocation and GCD is the number of fusions in heterozygosis. This is probably because the greater number of trivalent configurations in the spermatocytes increases the probability of an association with the $X Y$ bivalent, impairing the survival of the spermatocytes (e.g. Johannisson \& Winking 1994, Merico et al. 2003, Manterola et al. 2009). Our results are in accordance with those reported by other investigations of wild mice (Wallace et al. 1992, Hauffe \& Searle 1998) and hybrids from laboratory crosses between $\mathrm{Rb}$ races of mice from geographically distant populations (Wallace et al. 2002). Interestingly, $\mathrm{HH}$ mice showed lower mean $\beta: \alpha$ ratio values than 40ST mice and similar to those obtained for HTI-31 and HTI-39 mice. Previous studies, using wild mice or wild-derived strains, did not find differences between $\mathrm{Rb}$ homozygotes and the standard mice (e.g. Wallace et al. 1992, Hauffe \& Searle 1998, Merico et al. 2003). Unlike in those studies, $\mathrm{HH}$ mice from the $\mathrm{Rb}$ area of Barcelona are not a race (Sans-Fuentes et al. 2007), but are hybrids derived either from crosses 
between $\mathrm{HH}$ mice with equal karyotype or from crosses between mice with the same set of heterozygous $\mathrm{Rb}$ fusions. It is important to note that a) spermatogenesis is a very complex process that can be impaired by both structural and genetic incompatibilities and b) some different allelic variants could be linked to different metacentrics due to the suppression of recombination in $\mathrm{Rb}$ translocations (Davisson \& Akeson 1993, Dumas \& Britton-Davidian 2002). Therefore, $\mathrm{HH}$ mice from the $\mathrm{Rb}$ polymorphism area of Barcelona are likely to present a larger number of negative epistatic interactions than an established chromosomal race, since the latter has been under more generations of natural selection, and therefore allele combinations that disrupt spermatogenesis could have been eliminated from the population. It must also be pointed out that, although not statistically different, the mean $\beta: \alpha$ ratio values for $\mathrm{HTI}-31$ mice were slightly lower than HTI-39 mice. This could be due to a combined effect of structural heterozygosity and genetic incompatibilities similar to those discussed previously for $\mathrm{HH}$ mice. Other authors have suggested the relation of GCD with genetic incompatibilities in $\mathrm{Rb}$ mice (Said et al. 1993, Everett et al. 1996, Wallace et al. 2002). Even though different histological studies cannot be compared directly, especially if different methods for cell number correction are used (see Mouton (2002a)), the results obtained by Everett et al. (1996) are worth mentioning; they report high percentages of GCD (36.2-57.3\%) for heterozygote and homozygote animals for only one $\mathrm{Rb}$ fusion. In this case, the remarkably high GCD values could be due to incompatibilities in the genetic background, since these animals belong to a laboratory strain in which wild $\mathrm{Rb}$ fusions were introduced.

For the number of spermatocytes, the highest values of $\mathrm{Nv} \alpha$ were observed in the group HTI-31, mainly due to the high Nv $\alpha$ of two specimens (218 and 279, Table 1). These two animals have high values of GCD in their group and have Nva values higher than 40ST animals. This trend of high levels of spermatid death and high numbers of spermatocytes can be observed in other mice from the $\mathrm{Rb}$ polymorphism area of Barcelona, especially in multiple heterozygotes; for instance, mice 166 and 284 showed the lowest $\beta: \alpha$ ratio but had the highest $N v \alpha$ in their group (HTIII). This could be related to a mechanism to buffer cell death during meiosis by increasing the number of proliferative spermatogonia that start differentiating when cell death is significant. This phenomenon has been described for the case of complex Rb heterozygote mice with 2 and 16 metacentrics, in which the number of proliferative spermatogonia initiating differentiation was higher than in the standard mice (Redi et al. 1983, 1985).

The total number of spermatocytes (TN $\alpha$ ) and spermatids $(\mathrm{TN} \beta)$ in the testis showed a similar pattern to those found for the ratio $\beta: \alpha$. The group 40ST had the highest average, and the group HTIII had the lowest. While the pattern observed for TN $\beta$ was consistent with the results obtained for $N v \beta, T N \alpha$ and $N v \alpha$ showed different patterns. The results for TN should be interpreted with care, since they can be driven by testis volume, as ' $\mathrm{TN}=\mathrm{Nv} \times$ testis volume'. Assuming that $\mathrm{Nv}$ is homogeneous throughout the testis, and that the size of the testis is mainly determined by germ cell numbers (Yang et al. 1997), we may conclude that Rb mice produce a smaller total number of germ cells. If these assumptions are correct, the results obtained for TN suggest that GCD also occurs before the first meiotic division, either among the primary spermatocyte population or in the previous stages, for example, during the mitotic divisions that maintain the spermatogonia population. In fact, the existence of one pachytene checkpoint that arrests meiosis and induces cell elimination if the recombination or synapsis is altered has been postulated (Roeder \& Bailis 2000, Merico et al. 2003, 2008). Moreover, it has been observed that primary spermatocytes of $\mathrm{Rb}$ structural heterozygotes have alterations in the regulation of enzymatic activity (Hotta \& Chandley 1982), qualitative differences in the protein patterns (Forejt 1982, Merico et al. 2008), and longer prophase I (Redi et al. 1985).

In addition to the differences between chromosomal groups for the spermatogenic parameters analyzed, a high variability within the groups was detected. This suggests that other factors, such as metacentrics composition of the karyotypes (Gropp \& Winking 1981, Redi \& Capanna 1988, Searle 1993) and genetic incompatibilities (Said et al. 1993, Wallace et al. 2002), may also be playing an important role in the degree of spermatogenesis impairment.

The results of this study suggest that $\mathrm{Rb}$ translocations affect spermatogenesis by increasing GCD, especially when three heterozygous fusions are present. Nevertheless, we cannot discard other factors such as genetic incompatibilities or the metacentric composition of the karyotype. If this increase in GCD results in a reduction in male fertility, it could be a major cause of the reduction in gene flow between populations found previously in this area (Muñoz-Muñoz et al. 2003, 2006, Sans-Fuentes et al. 2005, 2009). Moreover, other selective pressures related to reproduction, such as the impairment of female gametogenesis and embryonic loss in crosses between animals with fusions, could play an important role in the reduction in gene flow between populations (Cattanach \& Moseley 1973, Epstein \& Travis 1979, Marchetti et al. 1999). Therefore, more detailed studies that examine, for example, female fertility and crosses in the laboratory between animals with different karyotypes should be conducted to evaluate the degree of isolation between populations of the $\mathrm{Rb}$ polymorphism area from Barcelona due to potentially negatively heterotic Rb rearrangements. 


\section{Materials and Methods}

\section{Animals}

The analysis of male reproductive organ size and the histology study of spermatogenesis were conducted on four chromosomal groups of mice from the $\mathrm{Rb}$ polymorphism area of Barcelona (Gündüz et al. 2001, Sans-Fuentes et al. 2007): homozygotes $(\mathrm{HH})$, animals with all the Rb fusions in structural homozygosis and with a diploid number ranging from $2 n=28$ to $2 n=30$; HTI-31, specimens with one $\mathrm{Rb}$ fusion in heterozygosis and four in homozygosis, and with $2 n=31$; HTI-39, specimens with one fusion in heterozygosis and $2 n=39$; and HTIII, mice with three heterozygous fusions and from zero to four fusions in homozygosis, and with a diploid number ranging from $2 n=29$ to $2 n=37$. These groups were established for chromosome number and structural heterozygosity-homozygosity. As a control, we used standard mice (40ST) from the area surrounding the $\mathrm{Rb}$ zone. It should be noted that both HTI-31 and HTI-39 have one Rb fusion in heterozygosis but differ in the number of homozygous metacentrics. This allows us to analyze whether there is an added effect on reproduction produced by the number of homozygous metacentrics, apart from the effect produced by structural heterozygosity.

For each category, adult mice were selected, i.e. sexually active animals with body mass higher than $12 \mathrm{~g}$ and body length longer than $75 \mathrm{~mm}$. An animal was classified as sexually active when smears from both right testis and right epididymis had spermatozoids (Gosàlbez et al. 1979). Size of reproductive organs (analysis of $\Omega_{0}$ space, see sampling strategy section; Fig. $1 \mathrm{~A})$ was studied in 61 mice $\left(n_{40 \mathrm{ST}}=17 ; n_{\mathrm{HH}}=11 ; n_{\mathrm{HTI}-31}=10\right.$; $n_{\mathrm{HTI}-39}=10$; and $n_{\mathrm{HTIII}}=13$ ) captured between March and September of 1996-2000. The histological study of spermatogenesis (analysis of $\Omega_{1}$ and $\Omega_{2}$ spaces, see sampling strategy section Fig. 1B-E) was conducted on a subset of the previous sample consisting of 25 mice (5 for each chromosomal group) captured between April and September of 1998. When selecting the animals of this subsample, we tried to minimize the heterogeneity of the following factors: sampling locality, $\mathrm{Rb}$ chromosome composition per chromosomal group, and reproductive season and year (Table 1 ).

\section{Sampling strategy, parameters calculations, and statistical analyses}

Reproductive data were obtained from multilevel sampling (Cruz-Orive \& Weibel 1981, Browne et al. 1995). Three levels of organization were analyzed as follows (Fig. 1): testis and seminal vesicle ( $\Omega_{\mathrm{o}}$ space), where the size of testis and seminal vesicle were measured; cross-section of the testis examined at $40 \times\left(\Omega_{1}\right.$ space $)$ to calculate the relative frequency of stages in the seminiferous epithelium cycle; and cross-section of the seminiferous tubule examined at $400 \times\left(\Omega_{2}\right.$ space $)$ to conduct a morphometric study of the seminiferous tubules and to quantify the cell population of the testis. In the space $\Omega_{\mathrm{o}}$, the data correspond with measurements of the left testis and seminal vesicle that were taken right after the animal was killed. To analyze the spaces $\Omega_{1}$ and $\Omega_{2}$, left testes were fixed in $4 \%$ formaldehyde solution. Then, the samples were treated by standard histological techniques (Durfort 1995), embedded in paraffin, cut into $5 \mu \mathrm{m}$ serial cross-sections using a rotation microtome (MICROM HM 330), and stained with periodic acid-Schiff and hematoxylin (Leblond \& Clermont 1952). Since distal areas of testis are rich in longitudinal sections of seminiferous tubules due to the great number of encirclements, the serial histological cross-sections were obtained from the third central part of the testis.

In $\Omega_{0}$ space, the size of left testis and left seminal vesicle were analyzed. Testis weight data were not available for all the animals. Nevertheless, we calculated the volume of the testis from the sagittal and transversal diameter $(4 / 3 \pi(1 / 2 \times$ sagital

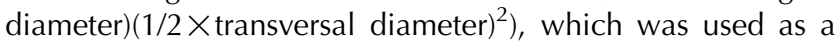
measurement of testis size. It has been reported that the specific mass of the testes is very close to $1 \mathrm{mg} / \mathrm{mm}^{3}$ (Russell et al. 1990); thus, testis volume in cubic millimeters is an approximation of testis mass in milligrams. The size of the seminal vesicle was the length from the junction of the two lobules to the external left end. Since the size of the testis and seminal vesicle can be related to body mass, these values were corrected by body mass (relative testis volume and relative seminal vesicle size respectively). Differences between the chromosomal groups for these variables were studied by one-way ANOVA.

In $\Omega_{1}$ space, the relative frequency of stages in the seminiferous epithelium cycle was calculated (Eaker et al. 2001) to determine whether the succession of maturation stages is altered in Rb mice. Two cross-sections were analyzed, the first was randomly selected in the central part of the testis and the second $50 \mu \mathrm{m}$ from the first one. These two crosssections correspond to one cross-section of each of the two dissectors used for cell count (see below). The seminiferous tubules studied in this space were selected by random systematic sampling (Fig. 1B and C; Gundersen \& Jensen 1987). Seminiferous tubules were classified for the stage of maturation of the epithelium, following Oakberg (1956), and stage frequencies were estimated for each cross-section. Mean frequency values of both cross-sections were calculated, and $\chi^{2}$-tests were used to analyze differences between the chromosomal groups.

In the space $\Omega_{2}$, two morphometric variables were measured on the same cross-sections used in the space $\Omega_{1}$ : the diameter of the tubule and the volume density of the epithelium. The former provides information about spermatogenic activity since there is a positive correlation between tubular diameter and spermatogenic activity (Sinha Hikim et al. 1989). The latter reveals information about the spermatogenic state of the tubules (Russell et al. 1990) since cell death during spermatogenesis can result in a thinner epithelium. The diameter of the tubule was obtained with a calibrated eyepiece micrometer. Only the minor axis of the tubule was measured since it does not vary if the section of the tubule taken is oblique. The volume density of the epithelium, i.e. the fraction of the seminiferous tubule occupied by the epithelium, was estimated following Cruz-Orive (1987). The areas were calculated by means of a coherent grid of equidistant points superimposed on the projection of the cross-section of the seminiferous tubule obtained by the camera lucida. 
The number of points captured for the lumen and the epithelium of the seminiferous tubule were counted (Fig. 1D).

Moreover, also in the space $\Omega_{2}$, the number of round spermatids $(\beta)$ and pachytene spermatocytes $(\alpha)$ were counted to calculate several informative variables of cell population in the testis, such as GCD, \% DT per animal, Nv $\beta$ and $N v \alpha$, and $\mathrm{TN} \beta$ and $\mathrm{TN} \alpha$. These estimates were obtained in the tubules selected in the previous space, but only stages I through VIII of maturation of the epithelium were used, since round spermatids can only be found in these stages. The cell numbers were quantified by the dissector principle, an unbiased method for calculating the total number of objects per unit of volume (for details, see Sterio (1984) and Mouton (2002b)). For each animal, two independent physical dissectors were used, the first was randomly selected in the central part of the testis and the second located $50 \mu \mathrm{m}$ from the first one. Fifty micrometers is a safe distance, at which the same cell cannot be sampled in the two cross-sections. Therefore, in the data analyses, the second dissector was considered a replica of the first one. In each dissector, the number of $\beta$ and $\alpha$ in each seminiferous tubule were obtained by radial sampling (angular intervals; Fig. $1 \mathrm{E}$ ). The $\beta: \alpha$ ratio was calculated to quantify GCD. The expected ratio is $4: 1$ if no GCD occurs or $0: 1$ if complete GCD occurs. The percentage of GCD was calculated as $100 \times(1-\beta /(4 \alpha))$. The distribution of cell death among tubules was estimated as the \% DT per animal, with the tubule considered as defective when the ratio $\beta: \alpha$ was lower than $3: 1$, i.e. that the number of spermatids divided by the number of spermatocytes was lower than 3 (Garagna et al. 1989). We calculated the percentage of tubules with $\beta: \alpha$ lower than 3:1 (\% DT<3), 2:1 (\% DT<2), and 1:1 (\% DT<1). These percentages were obtained by pooling both the cross-sections.

$N v \beta$ and $N v \alpha$ were calculated for each seminiferous tubule, following Sterio (1984). TN $\beta$ and $\mathrm{TN} \alpha$ were obtained by multiplying numeric densities by testis volume (Zirkin \& Ewing 1987). The volume of the testis of this set of animals was estimated from the mass of the testis, using as a specific mass $1.04 \mathrm{~g} / \mathrm{ml}$ (Russell et al. 1990).

Significant differences between groups of all the parameters obtained in this space, except for the \% DT, were studied by three-way nested ANOVA for non-balanced data. The fixed factors were the chromosomal group and animal; and the random factor, either the histological cross-section for the morphometric variables or the dissector for the variables derived from the cell counts. The chromosomal group was the main factor, the animal was nested in the chromosomal group, and the cross-section was nested in both the animal and chromosomal group. When the chromosomal group factor was significant, the Tukey test for multiple comparisons was performed. To further explore the differences between animals inside the chromosomal group, Student's $t$-test was performed between the mice with the Bonferroni correction applied (Rice 1989). To study the differences between chromosomal groups for the \% DT, one-way ANOVA was used, and then the post-hoc Tukey test was performed when ANOVA was significant. All the analyses were conducted by SAS (19992001; SAS Institute Inc., Cary, NC, USA). Data were reported as mean \pm S.E.M.
The normality of data was studied by the KolmogorovSmirnov test, and the homogeneity of variance was studied by Levene's test. Outliers, defined as lying beyond three times the interquartile amplitude, were eliminated from the analysis.

\section{Declaration of interest}

The authors declare that there is no conflict of interest that could be perceived as prejudicing the impartiality of the research reported.

\section{Funding}

This work was supported by a grant from the Spanish Ministerio de Ciencia y Tecnología (BMC2000-0541 and CGL2007$62111 /$ BOS), and by an FPI grant to MASF from the Spanish Ministerio de Ciencia y Tecnología.

\section{Acknowledgements}

Special thanks go to Alejandro Sánchez-Chardi for his help with the histological techniques, and to Robin Rycroft (Servei d'Assesorament Lingüístic, University of Barcelona) and Hoshin Gupta (University of Arizona) for making grammatical corrections to the manuscript.

\section{References}

Baker RJ \& Bickham W 1986 Speciation by monobrachial centric fusions. PNAS 83 8245-8248. (doi:10.1073/pnas.83.21.8245)

Basset P, Yannic G \& Hausser J 2008 Chromosomal rearrangements and genetic structure at different evolutionary levels of the Sorex araneus group. Journal of Evolutionary Biology 21 842-852. (doi:10.1111/ j.1420-9101.2008.01506.x)

Britton-Davidian J, Sonjaya H, Catalan J \& Cattaneo-Berrebi G 1990 Robertsonian heterozygosity in wild mice: fertility and transmission rates in $\mathrm{Rb}(16.17)$ translocation heterozygotes. Genetica 80 171-174. (doi:10.1007/BF00137322)

Browne MA, Howard CV \& Jolleys GD 1995 Principles of Stereology. In Image Analysis in Histology. Conventional and Confocal Microscopy, pp 96-121. Eds R Wootton, DR Springall \& JM Polak. Cambridge: Cambridge University Press.

Burgoyne PS \& Baker TG 1984 Meiotic pairing and gametogenetic failure. Symposia of the Society for Experimental Biology 38 349-362.

Burt G, Hauffe HC \& Searle JB 2009 New metacentric population of the house mouse (Mus musculus domesticus) found in Valchiavenna, Northern Italy. Cytogenetic and Genome Research 125 260-265. (doi:10.1159/000235931)

Capanna E \& Castiglia R 2004 Chromosomes and speciation in Mus musculus domesticus. Cytogenetic and Genome Research 105 375-384. (doi:10.1159/000078210)

Capanna E, Gropp A, Winking H, Noack G \& Civitelli MV 1976 Robertsonian metacentrics in the mouse. Chromosoma 58 341-353. (doi:10.1007/BF00292842)

Castiglia R \& Capanna E 2000 Contact zone between chromosomal races of Mus musculus domesticus. 2. Fertility and segregation in laboratoryreared and wild mice heterozygous for multiple Robertsonian rearrangements. Heredity 85 147-156. (doi:10.1046/j.1365-2540.2000.00743.x)

Cattanach BM \& Moseley H 1973 Nondisjunction and reduced fertility caused by the tobacco mouse metacentric chromosomes. Cytogenetics and Cell Genetics 12 264-287. (doi:10.1159/000130462)

Chatti N, Britton-Davidian J, Catalan J, Auffray JC \& Said K 2005 Reproductive trait divergence and hybrid fertility patterns between 
chromosomal races of the house mouse in Tunisia: analysis of wild and laboratory-bred males and females. Biological Journal of the Linnean Society 84 407-416. (doi:10.1111/j.1095-8312.2005.00443.x)

Clermont Y \& Trott M 1969 Duration of the cycle of the seminiferous epithelium in the mouse and hamster determined by means of ${ }^{3} \mathrm{H}$-thymidine and radioautography. Fertility and Sterility 20 805-817.

Cruz-Orive LM 1987 Stereology: historical notes and recent evolution. Acta Stereologica 6 (Suppl II) 43-56.

Cruz-Orive LM \& Weibel ER 1981 Sampling designs for stereology. Journal of Microscopy 122 235-257.

Davisson MT \& Akeson EC 1993 Recombination suppression by heterozygous Robertsonian chromosomes in the mouse. Genetics 133 649-667.

Dumas D \& Britton-Davidian J 2002 Chromosomal rearrangements and evolution of recombination: comparison of chiasma distribution patterns in standard and Robertsonian populations of the house mouse. Genetics 162 1355-1366.

Durfort M 1995 Algunes tècniques d'obtenció de preparacions d'estructures i de teixits animals. In Seminaris $d^{\prime}$ Estudis Universitaris, vol 4. Barcelona: Institut d'Estudis Catalans.

Eaker S, Pyle A, Cobb J \& Handel MA 2001 Evidence for meiotic spindle checkpoint from analysis of spermatocytes from Robertsonian-chromosome heterozygous mice. Journal of Cell Science 114 2953-2965.

Epstein CH \& Travis B 1979 Preimplantation lethality of monosomy for the mouse chromosome 19. Nature 280 144-145. (doi:10.1038/ 280144a0)

Everett CA, Searle JB \& Wallace MN 1996 A study of meiotic pairing, nondisjunction and germ cell death in laboratory mice carrying Robertsonian translocations. Genetical Research 67 239-247. (doi:10. 1017/S0016672300033723)

Fernández-Donoso R, Berrios S, Page J, Merani MS, Lizarralde MS, Vidal-Rioja L \& Bianchi NO 2001 Robertsonian chromosome polymorphism of Akodon molinae (Rodentia: Sigmodontinae): analysis of trivalents in meiotic prophase. Revista Chilena de Historia Natural 74 107-119. (doi:10.4067/S0716-078X2001000000016)

Forejt J $1982 \mathrm{X}-\mathrm{Y}$ involvement in male sterility caused by autosome translocations - a hypothesis. In Genetic Control of Gamete Production and Function, pp 135-151. Eds PG Crosignani \& BL Rubin. NewYork: Academic Press.

Franchini P, Castiglia R \& Capanna E 2008 Reproductive isolation between chromosomal races of the house mouse Mus musculus domesticus in a parapatric contact area revealed by an analysis of multiple unlinked loci. Journal of Evolutionary Biology 21 502-513. (doi:10.1111/j.14209101.2007.01492.x)

Garagna S, Zuccotti M, Searle JB, Redi CA \& Wilkinson PJ 1989 Spermatogenesis in heterozygotes for Robertsonian chromosomal rearrangements from natural populations of the common shrew, Sorex araneus. Journal of Reproduction and Fertility 87 431-438. (doi:10.1530/ jrf.0.0870431)

Garagna S, Zuccotti M, Thornhill A, Fernandez-Donoso R, Berrios S, Capanna E \& Redi CA 2001 Alteration of nuclear architecture in male germ cells of chromosomally derived subfertile mice. Journal of Cell Science 114 4429-4434.

Gosàlbez J, López-Fuster MJ \& Durfort M 1979 Ein neues Färbungsverfahren für Hodenzellen von Kleinsäugetieren. Säugetierkundliche Mitteilungen 40 303-305.

Gropp A \& Winking H 1981 Robertsonian translocations: cytology, meiosis, segregation pattern and biological consequences of heterozygosity. In Biology of the House Mouse, pp 141. Ed. RJ Berry. New York: Academic Press.

Gropp A, Winking H \& Redi CA 1982 Consequences of Robertsonian heterozygosity: segregational impairment of fertility versus male-limited sterility. In Genetic Control of Gamete Production and Function, Serono Clinical Colloquia on Reproduction, vol 3, pp 115-134. Eds PG Crosignani, BL Rubin \& M Fraccaro. New York: Academic Press.

Gundersen HJG \& Jensen EB 1987 The efficiency of systematic-sampling in stereology and its prediction. Journal of Microscopy 147 229-263.

Gündüz I, López-Fuster MJ, Ventura J \& Searle JB 2001 Clinal analysis of a chromosomal hybrid zone in the house mouse. Genetical Research 77 41-51. (doi:10.1017/S0016672300004808)

Hauffe HC \& Searle JB 1998 Chromosomal heterozygosity and fertility in house mice (Mus musculus domesticus) from northern Italy. Genetics 150 1143-1154.
Hausser J, Fedyk S, Fredga K, Searle JB, Volobouev V, Wójcik JM \& Zima J 1994 Definition and nomenclature of the chromosome races of Sorex araneus. Folia Zoologica 43 (Suppl 1) 1-9.

Hotta Y \& Chandley AC 1982 Activities of X-linked enzymes in spermatocytes of mice rendered sterile by chromosomal alterations. Gamete Research 6 65-72. (doi:10.1002/mrd.1120060108)

Jacobs PA 1981 Mutation-rates of structural chromosome rearrangements in man. American Journal of Human Genetics 33 44-54.

Jadwiszczak KA \& Banaszek A 2006 Fertility in the male common shrews, Sorex araneus, from the extremely narrow hybrid zone between chromosome races. Mammalian Biology 71 257-267. (doi:10.1016/ j.mambio.2006.02.004)

Johannisson R \& Winking H 1994 Synaptonemal complexes of chains and rings in mice heterozygous for multiple Robertsonian translocations. Chromosome Research 2 137-145. (doi:10.1007/BF01553492)

King M 1993 The impact of structural hybridity on fertility and viability. In Species Evolution: The Role of Chromosome Change, pp 126-170. Ed M King. Cambridge: Cambridge University Press.

Lanzone C, Gimenez MD, Santos JL \& Bidau CJ 2007 Meiotic effects of Robertsonian translocations in tuco-tucos of the Ctenomys perrensi superspecies (Rodentia: Ctenomyidae). Caryologia $60233-244$.

Leblond CP \& Clermont Y 1952 Spermiogenesis of rat, mouse, hamster and guinea pig as revealed by the "periodic acid-fuchsin sulfurous acid" technique. American Journal of Anatomy 90 167-215. (doi:10.1002/aja. 1000900202)

Manterola M, Page J, Vasco C, Berrios S, Parra MT, Viera A, Rufas JS, Zuccotti M, Garagna S \& Fernandez-Donoso RA 2009 A high incidence of meiotic silencing of unsynapsed chromatin is not associated with substantial pachytene loss in heterozygous male mice carrying multiple simple Robertsonian translocations. PLoS Genetics 5 e1000625. (doi:10. 1371/journal.pgen.1000625)

Mao X, Nie W, Wang J, Su W, Feng Q, Wang Y, Dobigny G \& Yang F 2008 Comparative cytogenetics of bats (Chiroptera): the prevalence of Robertsonian translocations limits the power of chromosomal characters in resolving interfamily phylogenetic relationships. Chromosome Research 16 155-170. (doi:10.1007/s10577-007-1206-2)

Marchetti F, Lowe X, Bishop J \& Wyrobek AJ 1999 Absence of selection against aneuploid mouse sperm at fertilization. Biology of Reproduction 61 948-954. (doi:10.1095/biolreprod61.4.948)

Meistrich ML 1982 Quantitative correlation between testicular cell survival, sperm production, and fertility in the mouse after treatment with different cytotoxic agents. Journal of Anatomy 3 58-68.

Merico V, Pigozzi MI, Esposito A, Merani MS \& Garagna S 2003 Meiotic recombination and spermatogenic impairment in Mus musculus domesticus carrying multiple simple Robertsonian translocations. Cytogenetic and Genome Research 103 321-329. (doi:10.1159/000076820)

Merico V, Diaz de Barboza G, Vasco C, Ponce R, Rodriguez V, Garagna S \& Tolosa de Talamoni N 2008 A mitochondrial mechanism is involved in apoptosis of Robertsonian mouse male germ cells. Reproduction 135 797-804. (doi:10.1530/REP-07-0466)

Miklos GLC 1974 Sex chromosome pairing and male sterility. Cytogenetics and Cell Genetics 13 558-577. (doi:10.1159/000130307)

Mouton PR 2002a Bias in estimating number. In Principles and Practices of Unbiased Stereology: An Introduction for Bioscientists, pp 61-70. Ed PR Mouton. Baltimore: The Johns Hopkins University Press.

Mouton PR 2002b The disector principle. In Principles and Practices of Unbiased Stereology: An Introduction for Bioscientists, pp 71-87. Ed PR Mouton. Baltimore: The Johns Hopkins University Press.

Muñoz-Muñoz F, Sans-Fuentes MA, López-Fuster MJ \& Ventura J 2003 Non-metric morphological divergence in the western house mouse, Mus musculus domesticus, from Barcelona chromosomal hybrid zone. Biological Journal of the Linnean Society 80 313-322. (doi:10.1046/ j.1095-8312.2003.00240.x)

Muñoz-Muñoz F, Sans-Fuentes MA, López-Fuster MJ \& Ventura J 2006 Variation in fluctuating asymmetry levels across a Robertsonian polymorphic zone of the house mouse. Journal of Zoological Systematics and Evolutionary Research 44 236-250. (doi:10.1111/j.1439-0469.2006.00357.x)

Oakberg EF 1956 A description of spermiogenesis in the mouse and its use in analysis of the cycle of the seminiferous epithelium and germ cell renewal. American Journal of Anatomy 99 391-413. (doi:10.1002/aja. 1000990303) 
de Oliveira EHC, Suemitsu E, Da Silva AF \& Sbalqueiro IJ 2000 Geographical variation of chromosomal number in Alouatta fusca clamitans (Primates, Atelidae). Caryologia 53 163-168.

Panithanarak T, Hauffe HC, Dallas JF, Glover A, Ward RG \& Searle JB 2004 Linkage-dependent gene flow in a house mouse chromosomal hybrid zone. Evolution 58 184-192. (doi:10.1111/j.0014-3820.2004.tb01585.x)

Piálek J, Hauffe HC \& Searle JB 2005 Chromosomal variation in the house mouse. Biological Journal of the Linnean Society 84 535-563. (doi:10. 1111/j.1095-8312.2005.00454.x)

Redi CA \& Capanna E 1988 Robertsonian heterozygotes in the house mouse and the fate of their germ cells. In The Cytogenetics of Mammalian Autosomal Rearrangements, pp 315-359. Eds A Daniel \& R Alan. New York: Liss.

Redi CA, Hilscher B \& Winking H 1983 Stage-dependent enzymatic activities in spermatogenesis of mice with the standard karyotype and of chromosomal variants with impaired fertility. Andrologia 15 322-330. (doi:10.1111/j.1439-0272.1983.tb00143.x)

Redi CA, Garagna S, Hilscher B \& Winking H 1985 The effects of some Robertsonian chromosome combinations on the seminiferous epithelium of the mouse. Journal of Embryology and Experimental Morphology 85 1-19.

Rice WR 1989 Analyzing tables of statistical tests. Evolution 43 223-225. (doi:10.2307/2409177)

Rieseberg LH 2001 Chromosomal rearrangements and speciation. Trends in Ecology \& Evolution 16 351-358. (doi:10.1016/S0169-5347(01) 02187-5)

Robinson TJ, Ruiz-Herrera A \& Avise JC 2008 Hemiplasy and homoplasy in the karyotypic phylogenies of mammals. PNAS 105 14477-14481. (doi:10.1073/pnas.0807433105)

Roeder GS \& Bailis JM 2000 The pachytene checkpoint. Trends in Genetics 16 395-403. (doi:10.1016/S0168-9525(00)02080-1)

Rogatcheva MB, Aulchenko YS, Oda SI, Zhelezova AI, Serova IA, Axenovich TI \& Borodin PM 2000 Chromosomal and genic mechanisms of reproductive isolation: the case of Suncus murinus. Acta Theriologica 45 (Suppl 1) 147-159.

Russell LD, Ettlin RA, Sinha Hikim AP \& Clegg ED 1990 Histology of the testis. In Histological and Histopathological Evaluation of the Testis, pp 210-226. Eds LD Russell, RA Ettlin, AP Sinha Hikim \& ED Clegg. Clearwater, FL: Cache River Press.

Said K, Saad A, Auffray JC \& Britton-Davidian J 1993 Fertility estimates in the Tunisian all-acrocentric and Robertsonian populations of the house mouse and their chromosomal hybrids. Heredity 71 532-538. (doi:10. 1038/hdy.1993.172)

Sans-Fuentes MA, López-Fuster MJ, Ventura J, Díez-Noguera A \& Cambras T 2005 Effect of Robertsonian translocations on circadian rhythm of motor activity in house mouse. Behavior Genetics 35 603-613. (doi:10.1007/s10519-005-5375-5)

Sans-Fuentes MA, Muñoz-Muñoz F, Ventura J \& López-Fuster MJ 2007 $\mathrm{Rb}(7.17)$, a rare Robertsonian fusion in wild populations of the house mouse. Genetical Research 89 207-213. (doi:10.1017/S0016672307008993)
Sans-Fuentes MA, Ventura J, López-Fuster MJ \& Corti M 2009 Morphological variation in house mice from the Robertsonian polymorphism area of Barcelona. Biological Journal of the Linnean Society 97 555-570. (doi:10.1111/j.1095-8312.2009.01237.x)

Searle JB 1993 Chromosomal hybrid zones in eutherian mammals. In Hybrid Zones and the Evolutionary Process, pp 305-353. Ed. RG Harrison. Oxford: Oxford University Press.

Searle AG \& Beechey CV 1974 Sperm count, egg-fertilization and dominant lethality after X-irradiation of mice. Mutation Research 22 63-72. (doi:10.1016/0027-5107(74)90009-8)

Sinha Hikim AP, Amador AG, Klemcke HG, Bertke A \& Russell LD 1989 Correlative morphology and endocrinology of Sertoli cells in hamster testes in active and inactive states of spermatogenesis. Endocrinology 125 1829-1843. (doi:10.1210/endo-125-4-1829)

Solano E, Castiglia R \& Corti M 2007 A new chromosomal race of the house mouse, Mus musculus domesticus, in the Vulcano Island-Aeolian Archipelago, Italy. Hereditas 144 75-77. (doi:10.1111/j.2007.0018-06 61.01988.x)

Spirito F 2000 The role of chromosomal rearrangements in speciation. In Endless Forms: Species and Speciation, pp 320-329. Eds DJ Howard \& SH Berlocher. Oxford: Oxford University Press.

Sterio DC 1984 The unbiased estimation of number and sizes of arbitrary particles using the dissector. Journal of Microscopy 134 127-136.

Theiler GR \& Blanco A 1996 Patterns of evolution in Graomys griseoflavus (Rodentia: Muridae). 2. Reproductive isolation between cytotypes. Journal of Mammalogy 77 776-784. (doi:10.2307/1382683)

Wallace BMW 2003 The effect of heterozygosity, genic or chromosomal, on fertility in the common shrew (Sorex araneus) and house mouse (Mus musculus domesticus). Mammalia 67 301-306. (doi:10.1515/ mamm.2003.67.2.301)

Wallace BMN, Searle JB \& Everett CA 1992 Male meiosis and gametogenesis in wild house mice (Mus musculus domesticus) from a chromosomal hybrid zone; a comparison between "simple" Robertsonian heterozygotes and homozygotes. Cytogenetics and Cell Genetics 61 211-220. (doi:10.1159/000133410)

Wallace BMN, Searle JB \& Everett CA 2002 The effect of multiple simple Robertsonian heterozygosity on chromosome pairing and fertility of wild-stock house mice (Mus musculus domesticus). Cytogenetic and Genome Research 96 276-286. (doi:10.1159/000063054)

Yang ZW, McLachlan RI, Bremner WJ \& Wreford NG 1997 Quantitative (stereological) study of normal spermatogenesis in the adult monkey (Macaca fascicularis). Journal of Anatomy 18 681-687.

Zirkin BR \& Ewing LL 1987 Leydig cell differentiation during maturation of the rat testis: a stereological study of cell number and ultrastructure. Anatomical Record 219 157-163. (doi:10.1002/ar.1092190208)

Received 22 May 2010

First decision 8 July 2010

Accepted 21 July 2010 